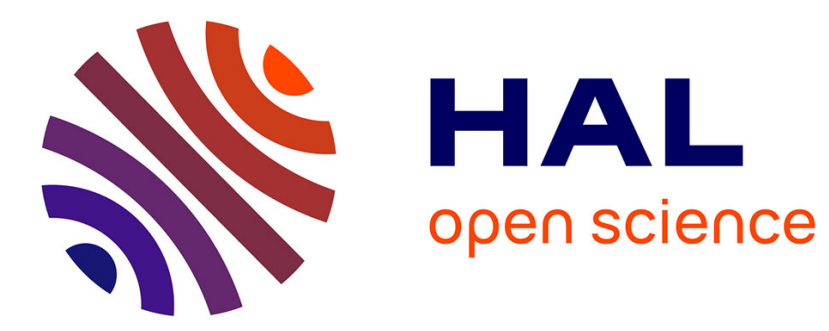

\title{
Unemployment and relative labor market institutions between trading partners
}

Hervé Boulhol

\section{To cite this version:}

Hervé Boulhol. Unemployment and relative labor market institutions between trading partners. 2010 . halshs-00544010

\author{
HAL Id: halshs-00544010 \\ https://shs.hal.science/halshs-00544010
}

Submitted on 7 Dec 2010

HAL is a multi-disciplinary open access archive for the deposit and dissemination of scientific research documents, whether they are published or not. The documents may come from teaching and research institutions in France or abroad, or from public or private research centers.
L'archive ouverte pluridisciplinaire HAL, est destinée au dépôt et à la diffusion de documents scientifiques de niveau recherche, publiés ou non, émanant des établissements d'enseignement et de recherche français ou étrangers, des laboratoires publics ou privés. 


\section{Documents de Travail du Centre d'Economie de la Sorbonne}

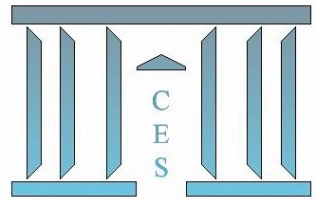

Unemployment and relative labor market institutions between trading partners

Hervé BOULHOL

2010.91

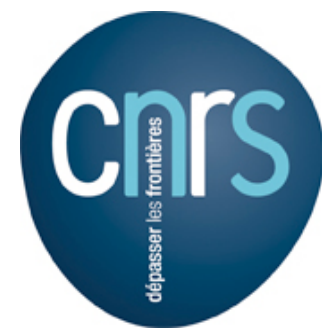




\title{
Unemployment and relative labor market institutions between trading partners *
}

\author{
Hervé Boulhol ${ }^{\star *}$ \\ University Paris I Panthéon-Sorbonne
}

September 2010

\begin{abstract}
This paper contributes to the literature that highlights the role of trading partners' institutions for a country's unemployment rate. The objective is to study whether the results established in the minimum wage setting of Davis (1998) hold when unemployment is driven by search frictions. This paper finds that relative labor market institutions matter for equilibrium unemployment as they generate comparative advantages, but there are two main differences with Davis. With North-North trade, unemployment decreases in the low-regulation country. When South is brought into the picture, lowregulation North is not insulated, and unemployment increases in both developed countries as a result of specialization.
\end{abstract}

Keywords: Unemployment, Labor Market Institutions, Trade

JEL Classification: F16, J50, F10, F41

\footnotetext{
* I am grateful to Matthieu Crozet, Romain Duval, Cyril Nouveau, Joaquim Oliveira-Martins and the participants of the Fourgeaud seminar for their helpful comments, as well as to the editor and two anonymous referees for having provided guidance to upgrade the paper substantially.
}

** 13 rue de Chabrol - 75010 Paris - France - 0033145248458 - herve.boulhol@oecd.org 


\begin{abstract}
Résumé
Cet article est une contribution à la littérature soulignant l'influence des institutions des partenaires commerciaux sur le taux de chômage d'un pays. L'objectif est d'étudier dans quelle mesure les résultats établis par Davis (1998) dans le cadre d'un modèle avec salaire minimum sont maintenus lorsque le chômage est dû à des frictions d'appariement. Ce papier montre que les institutions relatives du marché du travail affectent le taux de chômage d'équilibre dans la mesure où elles engendrent des avantages comparatifs, mais avec deux différences importantes par rapport à Davis. Avec du commerce Nord-Nord, le chômage baisse dans le pays faiblement réglementé. Lorsque le Sud est introduit, le pays du Nord légèrement réglementé est affecté, et le chômage augmente dans les deux pays du Nord à la suite de la spécialisation.
\end{abstract}

Mots-clés: Chômage, Institutions du marché du travail, Commerce

Classification JEL: F16, J50, F10, F41 
"A more subtle - but by this more important - reason for considering a global approach is that the consequences even of purely local institutions and shocks often depend crucially on the links to the global market"

Donald Davis

\section{Introduction}

The impact of labor market institutions on unemployment is generally assessed without taking into account increasing international economic linkages between countries. Despite globalization, most researchers focus on domestic labor market regulation to explain differences in unemployment rates both across countries and through time. This choice is motivated by theories of unemployment based on job search frictions, according to which more stringent domestic labor market regulation raises unemployment, an explanation herein referred to as the "regulation view". In doing so, the effect of foreign labor market institutions on domestic unemployment is thus ignored.

In their seminal paper, Blanchard and Wolfers (2000) highlight that, even though labor market institutions could explain much of the differences in unemployment across countries either in the 1980 s or the 1990s, changes in institutions were too small to account for the changes in unemployment rates. Blanchard and Wolfers find evidence that the mostly common shocks that affected developed countries, such as changes in real interest rate and productivity growth, had differentiated impacts on unemployment rates based on differences in labor market institutions. The rationale is, first, that rigidities can delay the adjustment of wages in the advent of negative shocks, which might generate unemployment, and, second, that differences in rigidities are related to differences in institutions. In contrast, Saint-Paul (2004) argues that changes in institutions have been significant in the last decades and can explain by themselves the magnitude of the trends in unemployment rates. ${ }^{1}$ In turn, Blanchard (2006) considers that these explanations are only partly satisfactory and encourages researchers to consider other shocks and other interactions.

\footnotetext{
${ }^{1}$ The most comprehensive effort to match the changes in unemployment rates with those in institutions is probably that of Nickell, Nunziata and Ochiel (2005) who find support for the regulation view and assess that the shock interactions à la Blanchard-Wolfers are not robust once added to their thorough specification. On the other hand, Baker, Glyn, Howell and Schmitt (2005) and Baccaro and Rei (2005) present a sceptical analysis of the evidence produced in support of the regulation
} 
This domestic focus is surprising given the prominent attention placed on the employment consequences of globalization in the public and political debate. Theoretically, Brecher (1974) shows how labor market rigidities generated by a binding minimum wage are magnified by international trade, and Davis (1998), building on Brecher's idea, draws attention to the key interactions between labor market institutions designed at the country level and global goods markets. ${ }^{2}$ In a stylized trade model between flexible wage "America" and minimum wage "Europe", Davis shows that trade ties up factor prices between countries and leads to an increase in long-term unemployment in "Europe". Davis' main intuition lies in the fact that "even when factor markets are strictly national, with idiosyncratic institutional features, they cannot be considered in isolation when goods markets are global". There is a major difference between the Blanchard-Wolfers hypothesis and the Brecher-Davis mechanism. The former seems implicitly optimistic in that the effects of labor market institutions, albeit persistent, are not a long-term phenomenon since "bad" institutions merely slow the necessary adjustments. In contrast, the Brecher-Davis interactions between trade and labor market institutions affect the unemployment rate in the long run.

The effects of a country's labor market regulations on its trading partners are the subject of a growing attention. Davidson and Matusz (2005), Moore and Ranjan (2005) and Cuñat and Melitz (2007) provide evidence that labor market institutions affect comparative advantages. Boulhol (2009) and Helpman and Itskhoki (2010) highlight how trade liberalisation affects unemployment through specialisation effects when countries differ in either union power or hiring costs, respectively. For example in Boulhol (2009), the threat of relocations, which trade integration makes even more credible, encourages labor market deregulation in the highly-regulated country to avoid capital outflows, thus leading to a decrease in unemployment. In an earlier contribution, Davidson, Martin and Matusz (1999) show that trade liberalisation between two countries, one of which is a capital-abundant large country with a more efficient labor market, leads to higher unemployment in that country. In these models, labor market regulation typically affects sectors asymmetrically, which generates

view. Following a rigorous empirical strategy, Bassanini and Duval (2006) reach more moderate conclusions as for the role of institutions, either directly or through the interactions with shocks.

2 In a different context, Krugman (1995) emphasizes that the impact of trade with developing countries on wages and employment depends on the functioning of the labor market: trade effects are likely to be mostly reflected by changes in wages in flexible economies and in employment in rigid ones. 
comparative advantages when either labor market institutions or factor endowments differ across countries. Dutt, Mitra and Ranjan (2009) focus on trade between countries having different development levels with search-generated unemployment. They show that unemployment increases with trade in the labor-scarce country if comparative advantages arise from differences in factor endowments, but decreases if they are based on relative technological differences, and find empirical support for the latter.

The current paper is part of the still nascent literature trying to incorporate unemployment in trade models. Its main contribution consists in investigating the extent to which Davis' main idea can be generalized to a broader type of labor market institutions than the simple minimum wage context. Using the two-factor matching framework of Pissarides (2000), the model developed herein highlights that foreign labor market institutions affect a country's unemployment rate through the trade channel. The main mechanism through which institutions of trading partners influence unemployment is straightforward. To the extent that labor market institutions matter for unemployment, they affect the cost of labor and, therefore, relative factor and good prices. It follows that labor market regulation contributes to comparative advantages in an open economy.

More specifically, the paper brings three main results. First, in the case of trade between two developed countries, as in Davis, the high-regulation ("rigid") country that has relative high labor costs tends to specialize in the capital-intensive good and unemployment increases as a result of the induced fall in labor demand. Second, and this is the main difference with Davis in the North-North context, the "flexible" economy benefits from trade with the "rigid" country in terms of total employment, through the induced increase in demand for the labor intensive good. Through trade and induced changes in factor prices, comparative advantages in labor market institutions enable the "flexible" economy to transfer some of the search-friction costs to the "rigid" economy. Third, when South is introduced to this North-North equilibrium, overall specialization results from the combination of endowment- and institution-driven comparative advantages. In the case where the endowment effect dominates, labor-abundant South specializes in the labor-intensive good. Consequently, unemployment decreases in the developing country and increases in both developed countries from their North-North equilibrium levels: in contrast with Davis, the "rigid" developed country does not 
absorb the whole permanent shock related to trade with South, and "flexible" North is also negatively affected in terms of employment. Combining North-North with North-South trade, the unemployment rate rises unambiguously from the autarky level in high-regulation North, whereas the total effect is ambiguous for low-regulation North.

The rest of the paper is organized as follows. Section 2 extends the matching model to a two-sector economy. Section 3 embeds this framework into a standard trade model focusing on North-North trade, while Section 4 introduces a labor abundant country into the picture. Finally, Section 5 concludes.

\section{A two-sector extension of Pissarides' matching framework}

This section embeds the large-firm version of the matching model of Pissarides (2000, chapter 3 ), which captures the main features of the regulation view, into a two-sector model. Each sector produces a homogeneous good under perfect competition. There are two factors of production, capital $K$ and labor $L$. The two factors could alternatively be thought of as being skilled and low skilled labor, as in Davis, with rigidities affecting mainly low skilled labor. This framework lays the ground for an extension of the Heckscher-Ohlin trade model to search frictions, which is developed in section 3.

Firms are identical within each sector, and sector 1 produces the capital-intensive good of price $p$ in terms of good 2, which is chosen as the numeraire. ${ }^{3}$ Let $K_{i j}$ and $L_{i j}$ be the capital and employment of firm $i$ in sector $j$, and let $F_{j}\left(K_{i j}, L_{i j}\right)$ be the constant returns-to-scale production function of all firms in that sector. Each firm is large enough so that there is no uncertainty about its flow of labor, and unemployed workers are assumed to be perfectly mobile across sectors. Wages are bargained at the individual level and firms choose the number of jobs by taking the bargained wages as given. Labor market characteristics are assumed to be identical in both sectors. ${ }^{4}$ While employed workers might be

\footnotetext{
${ }^{3}$ As goods are homogenous, all firms within the same sector set the same price.

${ }^{4}$ There are two reasons for this assumption. The first one is analytical simplicity. The second is that the impact of differences in labour market features across sectors on trade specialization has been studied elsewhere, as pointed out in the introduction. For example, Boulhol (2009) and Helpman amd Itskhorski (2010) consider differences in bargaining power and hiring costs, respectively. In these papers, the analytical complexity is resolved by assuming that there is no imperfection in one sector (i.e. it
} 
attached to the sector in which they work due to search frictions, it is assumed that unemployed workers have no attachment to a specific sector: they randomly take the first job possible. Hence, during a small interval $d t$, a vacant job is matched to an unemployed worker with the same probability $m(\theta) d t$ in both sectors, where $m($.$) is the matching function which decreases with labor market$ tightness, $\theta$, defined as the ratio of total vacancy to unemployment rates. Usual properties of the matching function, discussed at greater length in Pissarides (2000), are supposed to hold:

$$
m^{\prime}(\theta)<0 \quad, \quad\left|\theta m^{\prime}(\theta)\right|<m(\theta)
$$

such that $\theta m(\theta)$ increases with $\theta$. It is assumed that labor market tightness is exogenous to the firm's control and that each firm loses workers at the exogenous separation rate $\lambda$. Each vacancy costs the firm $h$ in recruitment costs and returns a worker at the rate $m(\theta)$. Therefore, denoting $V_{i j}$ the vacancies at firm $i$ in sector $j$, the law of motion of job is:

$$
\dot{L}_{i j}=-\lambda L_{i j}+m(\theta) V_{i j}
$$

Aggregating across all firms in each sector shows that in the steady-state:

$$
V_{j} / L_{j}=\lambda / m(\theta)
$$

Summing across sectors gives the steady-state unemployment rate:

$$
u=\frac{\lambda}{\lambda+\theta m(\theta)}
$$

Unambiguously, given (4), the unemployment rate is negatively related to labor market tightness. ${ }^{5}$

$I$ representing the investment of price $p_{K}, \delta$ the depreciation rate of capital stock, $w$ the gross wage, $h$ the cost of a vacant position and $r$ the discount rate, firm $i$ in sector $j$ maximizes the present-discounted value of expected profits:

$$
\underset{V_{i j}, I_{j i}}{\operatorname{Max}} \Pi_{i j}=\int_{0}^{\infty} e^{-r t}\left[p_{j} F_{j}\left(K_{i j}, L_{i j}\right)-w_{j} L_{i j}-h V_{i j}-p_{K} I_{i j}\right] d t \text { with } p_{1}=p \text { and } p_{2}=1
$$

\footnotetext{
is always possible to find a job in that sector). Differences between countries in labor market institutions (of the other sector) influence specialization. In contrast here, specialization is determined by the interactions between sectoral factor intensities and labour market institutions, which differ between countries but not across sectors.

${ }^{5}$ For example, referring to the previous footnote, if one allows for different separation rates across sectors, equation (4) remains valid, but with $\lambda=\lambda_{1} s_{1}+\lambda_{2}\left(1-s_{1}\right)$ where $s_{1}$ is share of employment in sector 1 , which is affected by specialization.
} 


$$
\text { s.c. } \quad \dot{K}_{i j}=I_{i j}-\delta K_{i j} \quad, \quad \dot{L}_{i j}=-\lambda L_{i j}+m(\theta) V_{i j}
$$

Let $k_{i j} \equiv K_{i j} / L_{i j}$ be the capital per unit of labor and $f_{j}\left(k_{i j}\right) \equiv F_{j}\left(K_{i j}, L_{i j}\right) / L_{i j}$. The first-order condition with respect to the investment decision implies that the capital-labor ratio is negatively related to the real user cost of capital (and is the same for all firms in a given sector; the $i$ sub-script is hence dropped below):

$$
\text { marginal product of capital }=p_{j} F_{j K}\left(K_{i j}, L_{i j}\right)=p_{j} f_{j}^{\prime}\left(k_{j}\right)=p_{K}(r+\delta) \equiv c_{K}
$$

The adjustment cost of labor, represented by $h$, creates a wedge between the marginal product of labor and the gross wage. Indeed, profit maximization entails that the marginal product of labor is equal to the sum of the gross wages, $w$, and the expected capitalized value of the firm's hiring costs:

$$
\text { marginal product of labor }=p_{j} F_{j L}\left(K_{i j}, L_{i j}\right)=p_{j}\left[f_{j}\left(k_{j}\right)-k_{j} f_{j}^{\prime}\left(k_{j}\right)\right]=w_{j}+\frac{h(\lambda+r)}{m(\theta)}
$$

$J_{o, j}$ and $J_{v, j}$ being the present-discounted values of expected profit from an occupied and vacant job in sector $j$, respectively, Bellman equations lead to:

$$
r J_{v, j}=-h+m(\theta)\left(J_{o, j}-J_{v, j}\right) \quad r J_{o, j}=p_{j} f_{j}\left(k_{j}\right)-p_{K}(r+\delta) k_{j}-w_{j}-\lambda\left(J_{o, j}-J_{v, j}\right)
$$

In equilibrium, profit opportunities drive rents from vacant jobs to zero, i.e. $J_{v, j}=0$, implying that profits from occupied jobs are the same in both sectors:

$$
J_{o, j}=\frac{h}{m(\theta)}=\frac{p_{j} F_{j L}-w_{j}}{\lambda+r}
$$

Let $W_{e, j}$ and $W_{u}$ denote the present-discounted value of the expected income stream of an employed worker in sector $j$ and of an unemployed worker, respectively. It follows that:

$$
\begin{aligned}
& r W_{u}=z+\theta m(\theta)\left(\frac{V_{1}}{V} W_{e, 1}+\frac{V_{2}}{V} W_{e, 2}-W_{u}\right) \\
& r W_{e, j}=w_{j} / \rho-\lambda\left(W_{e, j}-W_{u}\right)
\end{aligned}
$$

where $z$ and $\rho$ denote unemployment benefits and the tax wedge between gross and net of labor tax wages, respectively. ${ }^{6}$ Equation (3) implies that the sector shares in total vacant positions are equal to

\footnotetext{
${ }^{6}$ This type of framework typically ignores how unemployment benefits are financed and taxes spent.
} 
their respective sector employment shares, $s_{e, j}$. Using the expression of $W_{e, j}$ in (9b), equation (9a) becomes:

$$
\begin{aligned}
r W_{u} & =z+\theta m(\theta)\left[s_{e, 1}\left(\frac{w_{1} / \rho}{\lambda+r}+\frac{\lambda}{\lambda+r} W_{u}\right)+s_{e, 2}\left(\frac{w_{2} / \rho}{\lambda+r}+\frac{\lambda}{\lambda+r} W_{u}\right)-W_{u}\right] \\
& =z+\theta m(\theta)\left[\frac{\bar{w} / \rho}{\lambda+r}-\frac{r}{\lambda+r} W_{u}\right]
\end{aligned}
$$

where $\bar{w}$ is the average wage, and therefore:

$$
r W_{u}=\frac{(\lambda+r) z+\theta m(\theta) \bar{w} / \rho}{\lambda+r+\theta m(\theta)} \quad r W_{e, j}=\frac{\lambda z+(r+\theta m(\theta)) w_{j} / \rho+\lambda \theta m(\theta)\left(\bar{w}-w_{j}\right) / \rho /(\lambda+r)}{\lambda+r+\theta m(\theta)}
$$

The negotiated wage in each sector is the outcome of the Nash bargaining which boils down to maximizing the weighted product of the worker's and the net firm's surpluses from the match, the weight $\gamma$ representing workers' bargaining power: $w_{j}=\arg \max \left(W_{e, j}-W_{u}\right)^{\gamma}\left(\left(J_{o, j}-J_{v, j}\right) / \rho\right)^{1-\gamma}$. The first-order maximization condition satisfies: $W_{e, j}-W_{u}=\gamma\left(\left(W_{e, j}-W_{u}\right)+\left(J_{o, j}-J_{v, j}\right) / \rho\right)$ which, using equations (8) and (10) and after some manipulations, leads to:

$$
w_{j}+\frac{\theta m(\theta)}{\lambda+r}\left(w_{j}-\bar{w}\right)=\rho z+\frac{\gamma}{1-\gamma} \frac{h(\lambda+r+\theta m(\theta))}{m(\theta)}
$$

This proves that wages are the same across sectors: $w_{1}=w_{2} \equiv w$. In short, this result stems from the perfect mobility of unemployed workers and the assumption that both sectors have the same labor market characteristics. It enables to preserve all features of the one-sector model, as shown now.

It is straightforward to derive the expressions of the wage-setting and labor demand schedules from the above analysis. Using the equality of wages across sectors, equation (11) simplifies into:

$$
\text { wage setting: } \quad w=\rho z+\frac{\gamma}{1-\gamma} h\left[\theta+\frac{\lambda+r}{m(\theta)}\right]
$$

This positive relation between tightness and bargained wages is the wage-setting curve.

Combining (6a) and (6b) for the numeraire good defines a negative relationship between the marginal product of labor and the user cost of capital, $c_{K} \equiv p_{K}(r+\delta)$ :

$$
w+\frac{h(\lambda+r)}{m(\theta)}=g_{2}\left(c_{K}\right) \quad, \quad g_{2}{ }^{\prime}\left(c_{K}\right)=-k_{2}<0
$$


where $g_{2}\left(c_{K}\right) \equiv f_{2}\left(f_{2}^{\prime-1}\left(c_{K}\right)\right)-c_{K} f_{2}^{\prime-1}\left(c_{K}\right)$ depends on the characteristics of the numeraire good 2 . For a given user cost of capital, this expression implies a downward-sloping relationship between wages and labor-market tightness, which is similar to labor demand: ${ }^{7}$

$$
\text { labor demand: } \quad h(\lambda+r) / m(\theta)=g_{2}\left(c_{K}\right)-w \quad, \quad g_{2}{ }^{\prime}<0
$$

The wage-setting and labor-demand curves define the unique equilibrium determining labor market tightness as a function of the cost of capital and of the parameters characterizing labor market institutions:

$$
\text { labor market equilibrium: } \quad \gamma \theta+\frac{\lambda+r}{m(\theta)}=\frac{1-\gamma}{h}\left[g_{2}\left(c_{K}\right)-\rho z\right]
$$

which ensures that the following sensitivities are satisfied:

$$
\frac{\partial \theta}{\partial \gamma}<0, \frac{\partial \theta}{\partial z}<0, \frac{\partial \theta}{\partial \rho}<0, \frac{\partial \theta}{\partial r}<0, \frac{\partial \theta}{\partial h}<0, \frac{\partial \theta}{\partial \lambda}<0
$$

or equivalently given (4),

$$
\frac{\partial u}{\partial \gamma}>0, \frac{\partial u}{\partial z}>0, \frac{\partial u}{\partial \rho}>0, \frac{\partial u}{\partial r}>0, \frac{\partial u}{\partial h}>0, \frac{\partial u}{\partial \lambda}>0
$$

This extension of the Pissarides' matching model to a two-sector framework still captures the main features of the regulation view. Workers' bargaining power, and therefore, union density, is positively related to the unemployment rate, because a greater union power tends to push up wages, which reduces labor demand. An increase in the unemployment benefits leads to an increase in the unemployment rate, as it improves the outside option of workers in the bargaining process and therefore boosts wages. For the same reason, unemployment is positively related to the tax wedge, but only to the extent that an increase in the tax wedge, which drives down net wages, is not offset by lower unemployment benefits, i.e. to the extent that the wedge between net wages and benefits is reduced. ${ }^{8}$

\footnotetext{
${ }^{7}$ Section 3 shows that the focus on sector 2 is not restrictive: equilibrium conditions ensure that the reciprocal relation derived from sector 1 is actually identical (see below).

${ }^{8}$ Employment protection can be seen both as increasing the vacancy costs and as decreasing the separation rate. The former has a positive impact on the unemployment rate, while the latter has a negative one. Therefore, employment protection has an ambiguous effect overall in this framework.
} 


\section{Relative labor market institutions with respect to trading partners}

The purpose of this section is to introduce trade in this set-up, thus providing a theoretical framework in which the labor market institutions of trade partners affect a country's unemployment rate. Davis' (1998) rationale is followed closely by combining the two-sector matching model, developed in section 2, with the standard trade framework under homothetic preferences, keeping in mind that good 1 is assumed to be relatively capital intensive at any factor prices. Sub-section 3.1 deals with autarky and sub-section 3.2 with the open economy.

\subsection{Autarkic equilibrium}

In order to understand how factor endowments determine equilibrium unemployment based on domestic labor market regulation, it is convenient to explore the relationships between the user cost of capital and the unemployment rate in detail, first by focusing on the labor market, then on the product market.

What is the effect of changes in the user cost of capital on the unemployment rate in this two-factor framework, as a result e.g. of a change in relative endowments? According to the expression of the labour market equilibrium (eq. 15), an increase in the cost of capital triggers an increase in unemployment. Figure 1 represents the labor market equilibrium based on the labor-demand and wage-setting schedules. The equilibrium is initially at (EO). An increase in the cost of capital is associated with a shift in labor demand, which results in lower wages and higher unemployment. The new equilibrium is at (E1), and the mechanism is the following. A greater user cost of capital means a lower capital-labor ratio in both sectors such that the marginal product of capital increases to match the rise in the user cost. This adjustment in the capital-labor ratio is associated with a decrease in the marginal product of labor, $w+h(\lambda+r) / m(\theta)$, which results in a decrease in both wages and labor market tightness along the wage-setting schedule, hence a rise in unemployment. This mechanism by which an increase in the user cost of capital is associated with a higher unemployment level (and reciprocally for a decrease in the user cost) plays a key role in the open economy through changes in factor prices that are induced by trade with countries having either different labor market institutions or different factor endowments. 
In sum, the labor market equilibrium defines a positive relationship between the unemployment rate and both the cost of capital $c_{K}$ and the level of (unfavorable) labor market regulation ( $L M R$ ), which represents unemployment benefits, the tax wedge, the cost of search, etc.:

$$
\text { labor market equilibrium (RR) : } \quad u^{R R}=\alpha\left(c_{K}, L M R\right) \quad, \quad \partial \alpha / \partial c_{K}>0 \quad \partial \alpha / \partial L M R>0
$$

The function $\alpha$ captures the main features of the regulation view. It depends only on labor market institutions and the production functions (see eq. 15, and footnote 10 below), i.e. not directly on the country's factor endowments which effects on unemployment are channeled through the product market equilibrium only and the resulting capital cost level. The positive relation between the user cost of capital and the unemployment rate is represented by the positively-sloped $R R$ curve in Figure 2, where $R$ stands for regulation. The discussion in the previous section implies that an increase in (bad) regulation shifts the $R R$ curve to the upper left. This $R R$ curve holds for both autarky and trade equilibrium as it depends only on labor market regulation and technological parameters.

In autarky, the product market equilibrium through demand for both goods determines the cost of capital as a function of employed factor endowments. Indeed, according to the Heckscher-Ohlin theorem, there is a negative relation between the price of the capital intensive good and the effective capital-labor endowment:

$$
p=\zeta\left(\frac{K}{N(1-u)}\right)=\zeta\left(\frac{\kappa}{1-u}\right), \quad \zeta^{\prime}<0
$$

where $K$ is the country's capital stock, $N$ the labor force, and $\kappa \equiv K / N$ denotes relative endowments.

As long as the country produces both goods, the Stolper-Samuelson type-relation, adapted here to take into account the adjustment costs to labor, still implies a positive relation between $c_{K}$ and $p .^{9}$ Indeed, as shown in the previous section, wages and therefore the marginal products of labor are equalized across sectors at equilibrium, which implies:

$$
g_{2}\left(c_{K}\right)=f_{2}\left(k_{2}\right)-c_{K} k_{2}=p f_{1}\left(k_{1}\right)-c_{K} k_{1}=p g_{1}\left(c_{K} / p\right)
$$

\footnotetext{
${ }^{9}$ Using Samuelson (1962)'s terminology, the equilibrium factor price $c_{K}$ is obtained at the intersection of the factor price frontier of both goods at price $p$.
} 
where $g_{1}$ is the counterpart of $g_{2}$ for good $1 .^{10}$ Given that good 1 is capital intensive (i.e. $k_{1}>k_{2}$ at any factor prices), equation (20a) implicitly defines a positive relation between the relative price $p$ of the capital intensive good and the user cost of capital as differentiation leads to: ${ }^{11}$

$$
\frac{d p}{p}=\frac{\alpha_{2}^{K}\left(k_{1}-k_{2}\right)}{\alpha_{2}^{K} k_{1}+\left(1-\alpha_{2}^{K}\right) k_{2}} \frac{d c_{K}}{c_{K}}
$$

This also captures the well-known result that absolute changes in the user cost amplify absolute changes in the relative price of the capital-intensive good. This positive relation between the cost of capital and the price of the capital intensive good (eq. 20a) is denoted:

$$
c_{K}=\psi(p) \quad, \quad \psi^{\prime}>c_{K} / p>0
$$

The Heckscher-Ohlin and Stolper-Samuelson theorems (eq. 19 and 20b) characterize the productmarket equilibrium, which implies a negative relationship between the unemployment rate and both the cost of capital and the price of the capital-intensive good: an increase in the unemployment rate, by reducing the effective labor available to the economy, makes the labor intensive good relatively more expensive, hence a decrease in both $c_{K}$ and $p:^{12}$

$$
\text { product market equilibrium }\left(B D^{A}\right): \quad u_{A}^{B D}=1-\kappa / \zeta^{-1}(p), \quad \varsigma^{\prime}<0 \Leftrightarrow u_{A}^{B D}=\varphi\left(c_{K}\right), \quad \varphi^{\prime}<0
$$

Importantly, both decreasing functions only depend on the technical parameters of the production functions, on the relative factor endowment $\kappa \equiv K / N$ and on preferences. This means that labor

\footnotetext{
${ }^{10}$ Equation (20a) can also be written as $p_{2} g_{2}\left(c_{K} / p_{2}\right)=p_{1} g_{1}\left(c_{K} / p_{1}\right)$, which makes it clear that the focus on good 2 to characterize the labor market equilibrium (eq. 15) is innocuous as product market equilibrium links the user cost of capital to good prices based on the properties of both production functions. For example, (15) could be written as well as $\gamma \theta+(\lambda+r) / m(\theta)=(1-\gamma) / h\left[p g_{1}\left(c_{K} / p\right)-\rho z\right]$.

11 In this model, the usual properties of the Heckscher-Ohlin model, e.g. those linking changes in factor prices to changes in good prices are preserved, provided that wages are adjusted to take into account adjustment costs. That is, the appropriate price of labor should be taken as $\omega \equiv w+h(\lambda+r) / m(\theta)$. Differentiating (12) leads to $d \omega=d w-h(\lambda+r) m^{\prime} / m^{2} d \theta=\left[1-(1-\gamma) / \gamma(\lambda+r) m^{\prime} /\left(m^{2}-(\lambda+r) m^{\prime}\right)\right] d w$, which shows that wages and the adjusted labor price $\omega$ move in the same direction (given that $m^{\prime}<0$ ). One can check that when the match is perfect $(m(\theta)=1 \forall \theta), d \omega=d w$ or when $h \rightarrow 0$, then $\theta \rightarrow+\infty$ (i.e. $u \rightarrow 0$ ) and given (1) $m^{\prime} \rightarrow 0$ and $d \omega=d w$ also.

${ }^{12}$ It should be noted that the framework is a static one. Taking the dynamics of capital accumulation into account would amplify these mechanisms because of the substitution of capital to labor.
} 
market regulation does not affect this relation, which is labelled as the $B D$ locus in Figure 2, where $B D$ stands for Brecher-Davis, while $A$ stands for autarky in eq. 21 . Therefore, the autarkic equilibrium is defined at the intersection of the $B D$ and $R R$ schedules:

$$
u_{A}=\alpha\left(c_{K, A}, L M R\right) \quad, \quad u_{A}=1-\kappa / \zeta^{-1}\left(p_{A}\right) \quad, \quad c_{K, A}=\psi\left(p_{A}\right)
$$

For example, a more stringent regulation moves the $(R R)$ curve on the upper-left, increasing the unemployment rate while reducing the cost of capital (and the price of the capital-intensive good) along the $(B D)$ locus. Reciprocally, a decrease in capital endowment moves the $(B D)$ curve towards the upper-right, increasing the cost of capital (and $p$ ) and the unemployment rate along the $(R R)$ locus.

\subsection{The magnification effect of trade}

The mechanism highlighted by Davis, who treats the case of trade between a minimum wage and a flexible wage economy, is now extended to the labor market framework presented above. Suppose that two countries having the same relative factor endowments and preferences open up to trade: $\kappa \equiv \frac{K}{N}=\frac{K^{*}}{N^{*}} \equiv \kappa^{*}=\kappa^{W} \equiv \frac{K+K^{*}}{N+N^{*}}$ where the * and $W$ superscripts refer to the foreign country and the world, respectively. In that case, both countries share the same $B D$ locus in the closed economy, which is also the $B D$ relation in the integrated equilibrium linking the price $p$ to the world employed factors:

$$
u_{A}^{B D}=1-\kappa / \zeta^{-1}(p) \quad, \quad u_{A}^{B D^{*}}=1-\kappa / \zeta^{-1}\left(p^{*}\right), u_{T}^{B D, W}=1-\kappa / \zeta^{-1}(p)
$$

In autarky, the low regulation equilibrium is represented at point $A^{*}$ in Figure 2 for the foreign country. In the domestic country, assumed without loss of generality to have a more stringent regulation, the autarkic equilibrium settles at a point like $A$ along the common $B D$ locus. Stricter regulation implies a larger unemployment rate, and both a lower user cost of capital and price $p: u_{A}>u_{A}^{*}$ and $p_{A}<p_{A}^{*}$. Consequently because regulation affects relative prices it creates comparative advantages even if factor endowments are identical.

Let $s \equiv N /\left(N+N^{*}\right)$ be the share of the domestic country in world labor force. The world $R R$ curve is given straightforwardly as follows, since the world unemployment rate $u^{W}$ is equal to $s u+(1-s) u^{*}$ : 


$$
\left(R R_{T}^{W}\right): \quad u_{T}^{R R, W}=s u^{R R}+(1-s) u^{R R^{*}}=s \alpha\left(c_{K}, L M R\right)+(1-s) \alpha\left(c_{K}, L M R^{*}\right)
$$

Hence, the trade equilibrium is defined by:

$$
\begin{aligned}
& u_{T}=\alpha\left(c_{K, T}, L M R\right) \quad, \quad u_{T}^{*}=\alpha\left(c_{K, T}, L M R^{*}\right), \quad c_{K, T}=\psi\left(p_{T}\right) \\
& s \alpha\left[\psi\left(p_{T}\right), L M R\right]+(1-s) \alpha\left[\psi\left(p_{T}\right), L M R^{*}\right]=1-\kappa / \zeta^{-1}\left(p_{T}\right)
\end{aligned}
$$

It follows that trade amplifies the regulation-induced differences in unemployment rates between countries. Indeed, $\quad p_{A} \leq p_{T} \leq p_{A}^{*} \quad$ implies, according to eq. (23), that $u_{A}=u_{A}^{B D}\left(p_{A}\right) \geq u_{T}^{W}=u_{T}^{B D, W}\left(p_{T}\right) \geq u_{A}^{*}=u_{A}^{B D^{*}}\left(p_{A}^{*}\right)$ : in the trade equilibrium, the world unemployment rate lies in between the autarkic rates. Also, based on the $R R$ curves, $u_{T}=u^{R R}\left(p_{T}\right) \geq u^{R R}\left(p_{A}\right)=u_{A}$, and reciprocally $u_{T}^{*} \leq u_{A}^{*}$. Hence,

$$
u_{T} \geq u_{A} \geq u_{T}^{W} \geq u_{A}^{*} \geq u_{T}^{*}
$$

The trade equilibrium is represented in Figure $3 \mathrm{~A}$.

As a result, from autarky to trade, changes in the output mix induce the $(B D)$ locus to shift rightwards for the domestic high-regulated country and leftwards for the foreign low-regulated country. Indeed, for a given level of unemployment in the foreign country, $u^{*}$, equation (23) implies: ${ }^{13}$

$$
s u_{T}^{B D}+(1-s) u^{*}=1-\kappa / \zeta^{-1}(p)
$$

This defines the $(B D)$ locus in the trade equilibrium for the domestic country, in which the domestic unemployment rate is inversely related to the foreign unemployment rate as follows:

$$
\left(B D^{T}\right): u_{T}^{B D}=-\frac{1-s}{s} u^{*}+\frac{1-\kappa / \varsigma^{-1}(p)}{s} \equiv \mu\left(u^{*}, p\right) \quad, \quad \frac{\partial \mu}{\partial u^{*}}<0 \quad, \quad \frac{\partial \mu}{\partial p}<0
$$

Reciprocally, for the foreign country:

$$
\left(B D^{T^{*}}\right): u_{T}^{B D^{*}}=-\frac{s}{1-s} u+\frac{1-\kappa / \varsigma^{-1}(p)}{1-s} \equiv \mu^{*}(u, p) \quad, \quad \frac{\partial \mu^{*}}{\partial u}<0 \quad, \quad \frac{\partial \mu^{*}}{\partial p}<0
$$

the $B D$ schedules being linked by:

$$
s u_{T}^{B D}(p)+(1-s) u_{T}^{B D^{*}}(p)=1-\kappa / \zeta^{-1}(p)=u_{A}^{B D}(p)=u_{A}^{B D^{*}}(p)
$$

\footnotetext{
${ }^{13} \mathrm{I}$ am especially grateful to one anonymous referee for having suggested this formalization.
} 
With trade, each country's $B D$ curve depends on the other country's effective endowments, i.e. the other country's unemployment rate. Therefore, as an alternative to eq. (25), the trade equilibrium can be characterized by:

$$
u_{T}=\alpha\left(c_{K, T}, L M R\right) \quad, \quad u_{T}^{*}=\alpha\left(c_{K, T}, L M R^{*}\right) \quad, \quad c_{K, T}=\psi\left(p_{T}\right) \quad, \quad u_{T}=\mu\left(u_{T}^{*}, p_{T}\right)
$$

As one can easily verify that the autarky (BD) loci are given by $u_{A}=\mu\left(u_{A}, p_{A}\right)$ and $u_{A}^{*}=\mu^{*}\left(u_{A}^{*}, p_{A}^{*}\right)=\mu\left(u_{A}^{*}, p_{A}^{*}\right)$, equations (28a-c) imply the aforementioned shifts from autarky to trade. The underlying channel is specialization through trade along the following line.

Due to differences in labor market regulation, this world behaves as if Home is relatively capital abundant. At the domestic autarky price, foreign demand for the capital intensive good increases, the more so the lower the regulation in the foreign country (as it implies a higher $p_{A}^{*}$ ). The resulting boost in the Home price of the capital-intensive good generates an increase in the user cost of capital, which rises unemployment. Due to labor market rigidities, supplying more of the capital-intensive good can only happen if the domestic economy becomes effectively more capital abundant by shifting resources to the capital-intensive sector, thus generating an increase in unemployment.

Figure 3B illustrates how the $B D$ curves shift with trade. Equilibrium in the domestic and foreign country are shown in the North-East and South-East quadrant, respectively, with autarky at points $A$ and $A^{*}$. The assumption that both countries have the same relative factor endowments is reflected by both countries having the same (symmetric in the chart) $(B D)$ locus in autarky. Because the domestic country has a more stringent labor market regulation, the autarkic unemployment rate is higher than in the foreign country. The integrated equilibrium $W$ settles at a price $p_{T}$, which lies somewhere between $p_{A}$ and $p_{A}^{*}$ based on the relative size of the two countries. The North-West quadrant represents the negative relationship between the unemployment rates in both countries at price $p_{A}$ and $p_{T}$ according to $u=\mu\left(u^{*}, p_{A}\right)$ and $u=\mu\left(u^{*}, p_{T}\right)$, respectively. Finally, the South-West quadrant uses the $45^{0}$ line to transform the foreign unemployment rate from the North-West to the South-East quadrant. Starting from $p=p_{A}$, the domestic $R R$ curve implies $u=u_{A}$ and, according to $u=\mu\left(u^{*}, p_{A}\right), u^{*}=u_{A}$, which in turn based on $R R^{*}$ would mandate a price $p^{*}>p=p_{A}$ clearly 
inconsistent with the trade equilibrium. Any point on the South-West of $A$ along the domestic $R R$ schedule will produce a similar outcome. Price convergence occurs therefore at a price such as $p_{T}$ whereby the equilibrium in each country moves along their respective $R R$ locus at points $T$ and $T^{*}$ : because the domestic country specializes in the capital-intensive good, the $B D$ locus shifts rightwards for the domestic country and leftwards for the foreign country according to (28a-c).$^{14}$ In the domestic country, trade induces a joint increase in the user cost of capital and the unemployment rate, while the converse applies to the foreign country, leading to the aggregated unemployment rate $u^{W}$.

In this model the unemployment rate of a given country is therefore negatively related to the regulation level of its trading partner. ${ }^{15}$ Hence, the qualitative results obtained by Davis are extended to a more general context, with one noticeable difference. In Davis, the low regulation country has flexible wages and therefore no unemployment in autarky, as well as in the trade equilibrium. With labor market frictions, the low regulation country benefits from trade with a high regulation country in terms of employment, through a decrease in the user cost of capital, which boosts labor demand. Davis' special (and extreme) case, where regulation is limited to minimum wages in one country, is obtained as follows, with $s=1 / 2$. The labor market in the flexible economy implies $u_{T}^{*}=0, \forall p$, while the binding minimum wage in the rigid one induces $p_{T}=p_{A}$. Hence, $u_{T}=\mu\left(u_{T}^{*}, p_{T}\right)=2\left[1-\kappa / \zeta^{-1}\left(p_{A}\right)\right]=2 u_{A}$ : the unemployment rate doubles in the domestic country. Davis' case is quantitatively extreme as eq. (26) implies that with $s=1 / 2$ the doubling of the unemployment rate in the rigid country is an upper bound.

\footnotetext{
${ }^{14}$ Factors are supposed to be immobile internationally in the Heckscher-Ohlin context. This can be problematic if $K$ is explicitly thought of as physical capital. However, in such a case, low return to capital in the "rigid" economy would lead to capital outflows that would shift the $B D$ schedule rightwards. This would produce similar results to the case of trade without capital mobility, because factor mobility is a substitute for trade in this model.

${ }^{15}$ If there remain some impediments to trade, full convergence to the world price is not complete. As a result, the equilibrium would be somewhere between $A$ and $T$ for the domestic country and between $A^{*}$ and $T^{\star}$ for the foreign country, depending on the level of trade costs.
} 


\section{North-South trade}

\subsection{One North, one South}

When countries have different relative factor endowments $\left(\kappa^{S}<\kappa^{N}\right)$, labor market institutions contribute to the establishment of comparative advantages on top of those driven by endowment differences. $s^{N}$ being the share of North in the world labor force, the world $R R$ schedule is still given by:

$$
\left(R R_{T}^{W}\right): \quad u_{T}^{R R, W}=s^{N} \alpha\left(c_{K}, L M R^{N}\right)+\left(1-s^{N}\right) \alpha\left(c_{K}, L M R^{S}\right)
$$

Differences in relative endowments imply that the two countries have different $B D$ schedules:

$$
u_{A}^{B D, N}=1-\kappa^{N} / \zeta^{-1}\left(p^{N}\right) \quad, \quad u_{A}^{B D, S}=1-\kappa^{S} / \zeta^{-1}\left(p^{S}\right)
$$

The world trade $B D$ curve, $u_{T}^{B D, W}(p)=1-\kappa^{W} / \zeta^{-1}(p)$, is thus a weighted average of the countries' autarkic $B D$ curves as $\kappa^{W}=s^{N} \kappa^{N}+\left(1-s^{N}\right) \kappa^{S}$ :

$$
\left(B D_{T}^{W}\right): \quad u_{T}^{B D, W}(p)=1-\kappa^{W} / \zeta^{-1}(p)=s^{N} u_{A}^{B D, N}(p)+\left(1-s^{N}\right) u_{A}^{B D, S}(p)
$$

Hence, it is a general feature that the integrated $R R$ and $B D$ schedules are the labor-force-weighted average of the countries' (autarky) schedules. As a result, the trade equilibrium price $p_{T}$ is given by eqs. (30) and (32), with $c_{K, T}=\psi\left(p_{T}\right)$.

Given labor market regulation in both countries, North will have a comparative advantage in the capital-intensive sector if it is effectively capital abundant: $p_{A}^{N}<p_{A}^{S} \Leftrightarrow \kappa^{N}>\kappa^{S} \frac{1-u_{A}^{N}}{1-u_{A}^{S}}$. With trade, the North $B D$ locus shifts as follows, given eq. (32):

$$
u_{T}^{B D, N}=-\frac{1-s^{N}}{s^{N}} u^{S}+\frac{1-\kappa^{W} / \varsigma^{-1}(p)}{s^{N}} \equiv \mu^{N}\left(u^{S}, p\right), \quad \frac{\partial \mu^{N}}{\partial u^{S}}<0, \quad \frac{\partial \mu^{N}}{\partial p}<0
$$

while the trade equilibrium is now given by:

$$
u_{T}^{N}=\alpha\left(c_{K, T}, L M R^{N}\right) \quad, \quad u_{T}^{S}=\alpha\left(c_{K, T}, L M R^{S}\right) \quad, \quad u_{T}^{N}=\mu^{N}\left(u_{T}^{S}, p_{T}\right) \quad, \quad c_{K, T}=\psi\left(p_{T}\right)
$$

Assume first that both countries have the same regulation, with North being capital rich / labor scarce relative to South. Differences in relative endowments imply that the $B D$ schedule differs between the two countries in autarky, and autarky equilibrium is at a point like $N$ in North and $S$ in South in Figure 
4: the labor abundant country has both a higher cost of capital and unemployment rate. As a result of specialization, the integrated equilibrium is at a point like $W$ on the common $R R$ schedule, ensuring convergence of the unemployment rate across countries according to (18) as a result of price convergence. In this model with search frictions, trade leads to an increase in unemployment in the labor scarce country and to a decrease in the labor abundant country, a result that bears some resemblance with the analysis of Davidson et al. (1999), and is consistent with the Hechscher-Ohlin framework of Dutt et al. (2009) even though the settings are different.

When differences in labor market regulation are brought into the picture, comparative advantages are driven by both differences in endowments and in labor market institutions, with the total effect combining those in Figure 3 (differences in institutions only) and Figure 4 (differences in endowments only): high regulation in the developed country relative to the developing country amplify the endowment-driven comparative advantages, whereas the latter would be attenuated, and potentially reversed, if the developing country highly regulates.

\subsection{Two North, one South}

The final case investigates the impact of trade with a labour-intensive country (South) on a pair of developed countries (North, domestic and foreign) with low- and high-regulated labor market. The $B D$ locus in the trade equilibrium is still given by $u_{T}^{B D, W}(p)=1-\kappa^{W} / \zeta^{-1}(p)$ $=s s^{N} u_{A}^{B D, N}(p)+(1-s) s^{N} u_{A}^{B D, N^{*}}(p)+\left(1-s^{N}\right) u_{A}^{B D, S}(p)$, where $s$ is the share of the domestic country in North labor force, which implies:

$$
\left(B D^{T, N}\right): \quad u_{T}^{B D}=-\frac{1-s}{s} u^{*}-\frac{1-s^{N}}{s s^{N}} u^{S}+\frac{1-\kappa^{W} / \varsigma^{-1}(p)}{s s^{N}} \equiv \mu^{N}\left(u^{*}, u^{S}, p\right)
$$

Provided that each of the three countries produces both goods, the full equilibrium is given by:

$$
\begin{aligned}
& u_{T}=\alpha\left(c_{K, T}, L M R\right), u_{T}^{*}=\alpha\left(c_{K, T}, L M R^{*}\right), u_{T}^{S}=\alpha\left(c_{K, T}, L M R^{S}\right) \\
& u_{T}=\mu\left(u_{T}^{*}, u_{T}^{S}, p_{T}\right), c_{K, T}=\psi\left(p_{T}\right)
\end{aligned}
$$

As in Davis, it is helpful to start from the equilibrium corresponding to free-trade between the developed countries, as represented in Figure 3, then to introduce of a previously isolated laborintensive country, South, and apply the North-South analysis developed in the previous sub-section. If, 
given labor market regulations, South maintains a comparative advantage in the labor-intensive good, i.e. if $p_{A}^{S}>p_{N}^{N}$, where $p_{N}^{N}$ is the price in the North-North equilibrium, the world cost of capital will increase from its North-North level triggering an increase in unemployment in both Northern countries along their respective $R R$ schedule. Contrary to Davis, the high-regulated developed country does not absorb the whole shock. In contrast, the user cost will fall from its autarky level in South, inducing a decrease in unemployment. Compared with autarky, unemployment raises unambiguously in the highregulated developed country. In the low-regulated developed country, however, trade with North and with South produce opposite effects, such that the overall change in unemployment is undetermined.

\section{Conclusion}

There is ample evidence that a country's labor market institutions are important determinants of unemployment, either directly or through the propagation of shocks. This paper contributes to the growing awareness that, with globalization, the institutions of trading partners matter also for a country's equilibrium unemployment rate. Because labor market institutions affect relative prices, they contribute to comparative advantages and boost or weaken demand for labor intensive goods depending on differences in labor market regulations between countries. When labor markets work perfectly, wages adjust to ensure full employment. In contrast, in the presence of rigidities, shifts in sectoral demands affect unemployment. Consequently, trade might magnify the consequences of the institutional setting on total employment. ${ }^{16}$

Davis (1998) highlights such a mechanism in a Heckscher-Ohlin trade model between two developed countries with identical factor endowments, in the special case where one country has a flexible-wage and the other a minimum-wage labor market. This paper asks whether Davis' results extend to the workhorse labor market search framework of Pissarides (2000), which is embedded into a two-sector context. In Davis, trade between these two countries induces a doubling of unemployment in the minimum-wage economy while full employment is maintained in the flexible country. With searchgenerated unemployment, it is shown herein that the unemployment rate increases in the high-

\footnotetext{
${ }^{16}$ Eventually trade might "discipline" labor market institutions; Boulhol, Dobbelaere and Maioli (2010) provide some evidence that rising imports from developed countries exerted downward pressure on workers' bargaining power in the United Kingdom.
} 
regulation country (although it less than doubles), but decreases in the low-regulation one. When trade with a developing country is brought into this setting, comparative advantages result from both relative factor endowments and relative labor market institutions. Assuming that South specializes in the labor intensive sector, unemployment increases in both developed countries relative to their respective North-North integrated trade equilibrium levels. Hence, the specific Davis' case in which the minimum wage of its Northern trading partner insulates the flexible-wage country from the (negative) impact of trade with South on total employment does not hold any more. In fact, unemployment might even rise more in the low-regulation country, albeit from a lower level, depending on the specific parameters of both labor markets.

Confirmation of these theoretical results could have important policy implications. Economic integration might foster labor market deregulation because of the dissuasive costs of maintaining a high level of regulation in the open economy. In addition, incentives to non-cooperatively deregulate the labor market might be reinforced with integration and, by anticipation, the desire to preserve the so-called "social models" might create resistance to opening up to low-regulation economies. Also, deregulating the labor market might generate a negative externality for trading partners, raising the possibility that cooperation in setting labor market policies enables to reach a better equilibrium.

\section{References}

Baccaro, L., Rei, D., 2005. Institutional determinants of unemployment in OECD countries: A time series crosssection analysis (1960-1998). ILO Discussion Paper No 160.

Baker, D., Glyn, A., Howell, D.R., Schmitt, J., 2005. Labor Market Institutions and Unemployment: A Critical Assessment of the Cross-Country Evidence, in Fighting Unemployment: The Limits of Free Market Orthodoxy, D.R. Howell, ed., Oxford University Press.

Bassanini, A., Duval, R., 2006. Employment patterns in OECD countries: Reassessing the role of policies and institutions. OECD Economic Studies 42 (1), 7-86.

Blanchard, O., 2006. European unemployment: the evolution of facts and ideas. Economic Policy 21 (45), 5-59.

Blanchard, O., Wolfers, J., 2000. The role of shocks and institutions in the rise of European unemployment: the aggregate evidence. Economic Journal 110, C1-33.

Boulhol, H., 2009. Do capital market and trade liberalization trigger labor market deregulation? Journal of International Economics 77 (2), 223-233.

Boulhol, H., Dobbelaere S., Maioli S., 2010. Imports as product and labor market discipline. British Journal of Industrial Relations, forthcoming. 
Brecher, R., 1974. Minimum wage rates and the pure theory of international trade. Quarterly Journal of Economics 88, 98-116.

Cuñat, A., Melitz, M., 2007. Volatility, labor market flexibility, and the pattern of comparative advantage. NBER Working Paper No. 13062.

Davidson, C., Martin, L., Matusz, S., 1999. Trade and search generated unemployment. Journal of International Economics 48, 271-299.

Davidson, C., Matusz, S., 2005. Trade and turnover: Theory and evidence. Review of International Economics 13 (5), 861-880.

Davis, D.R., 1998. Does European unemployment prop up American wages? National labor markets and global trade. American Economic Review 88 (3), 478-494.

Dutt, P., Mitra, D., Ranjan, P., 2009. International trade and unemployment : Theory and cross-national evidence. Journal of International Economics 78, 32-44.

Helpman, E., Itskhoki, O., 2010. Labor market rigidities, Trade and Unemployment. Review of Economic Studies 77(3), 1100-1137.

Krugman, P.R., 1995. Growing world trade : Causes and consequences, Brookings Papers on Economic Activity 1, 327-362.

Moore, M.P., Ranjan, P., 2005. Globalisation vs skill-biased technological change: Implications for unemployment and wage inequality. Economic Journal 115, 391-422.

Nickell, S., Nunziata, L., Ochel, W., 2005. Unemployment in the OECD since the 1960s. What do we know? Economic Journal 155, 1-28.

Pissarides, C., 2000. Equilibrium Unemployment Theory, Cambridge, MA, MIT Press.

Saint-Paul, G., 2004. Why are European countries diverging in their unemployment experience? Journal of Economic Perspectives 18 (4), 49-68.

Samuelson, P.A.,1962. Parable and Realism in Capital Theory: The Surrogate Production Function, Review of Economic Studies 29, 193-206. 
Figure 1

Labor market equilibrium and the impact of

an increase in the user cost of capital

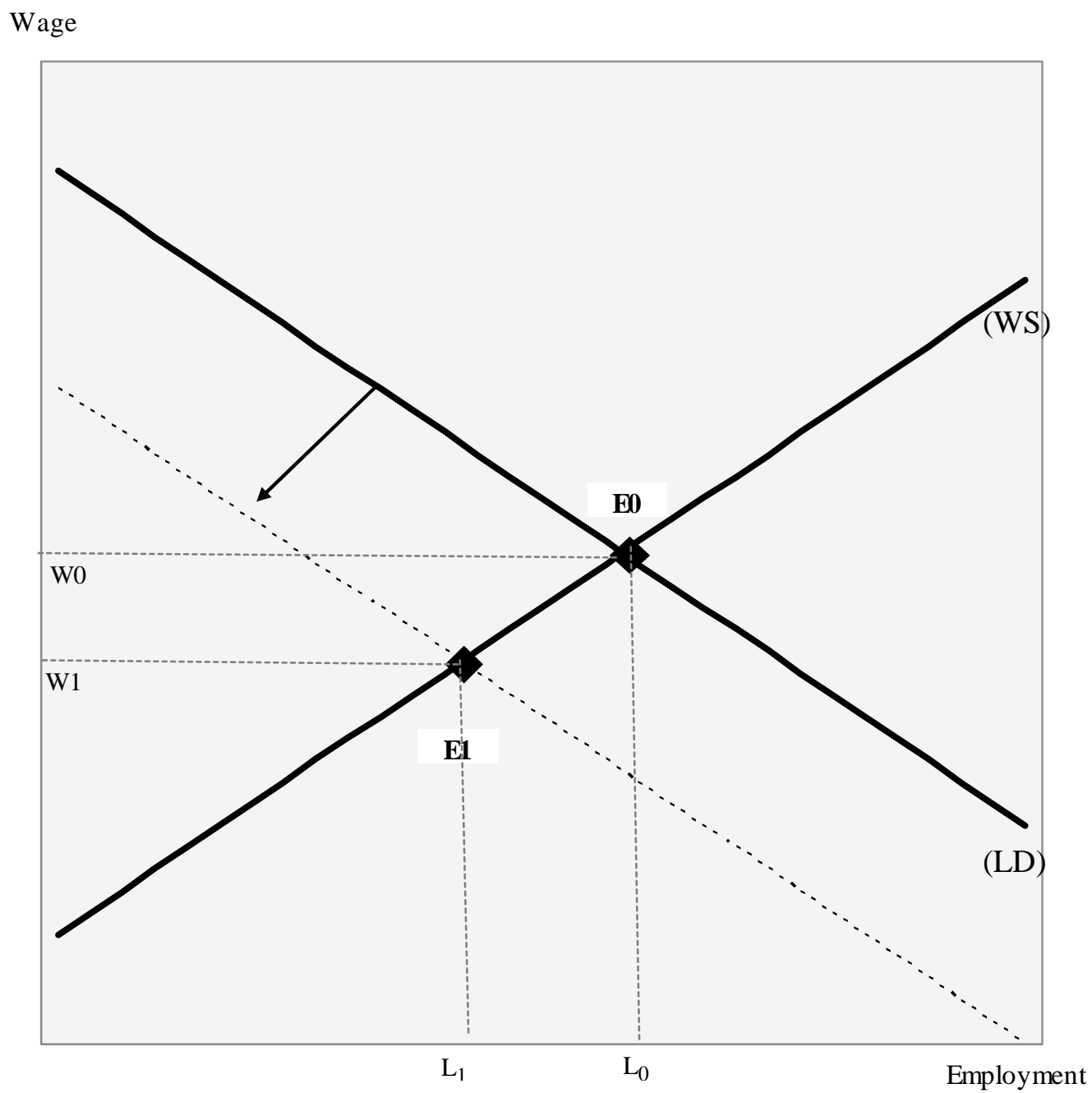

(LD): labor demand schedule

(WS): wage-setting / labor supply schedule 
Figure 2

Regulation view in a two-sector model

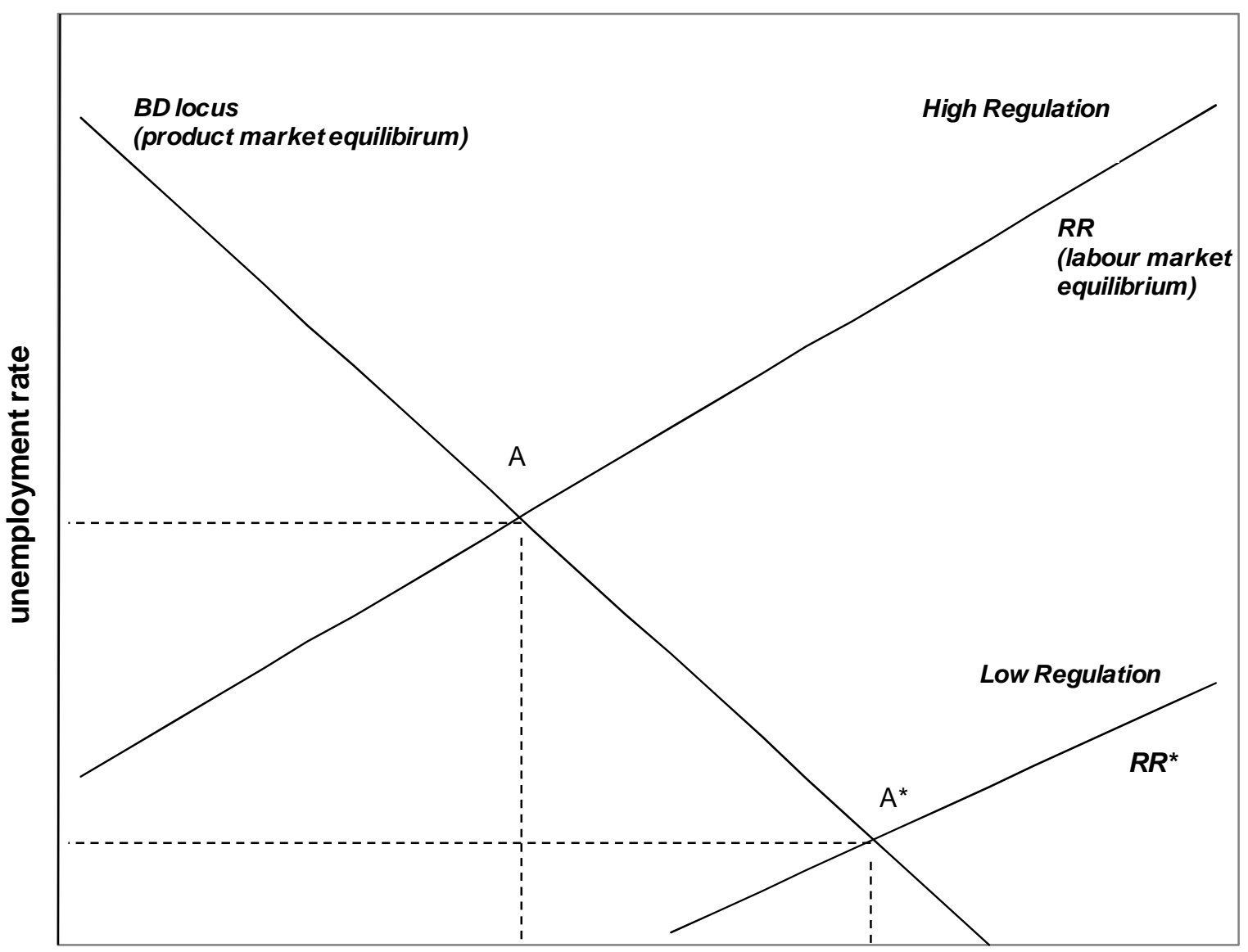

user cost of capital 
Figure 3A

Trade between two countries having identical relative factor endowment

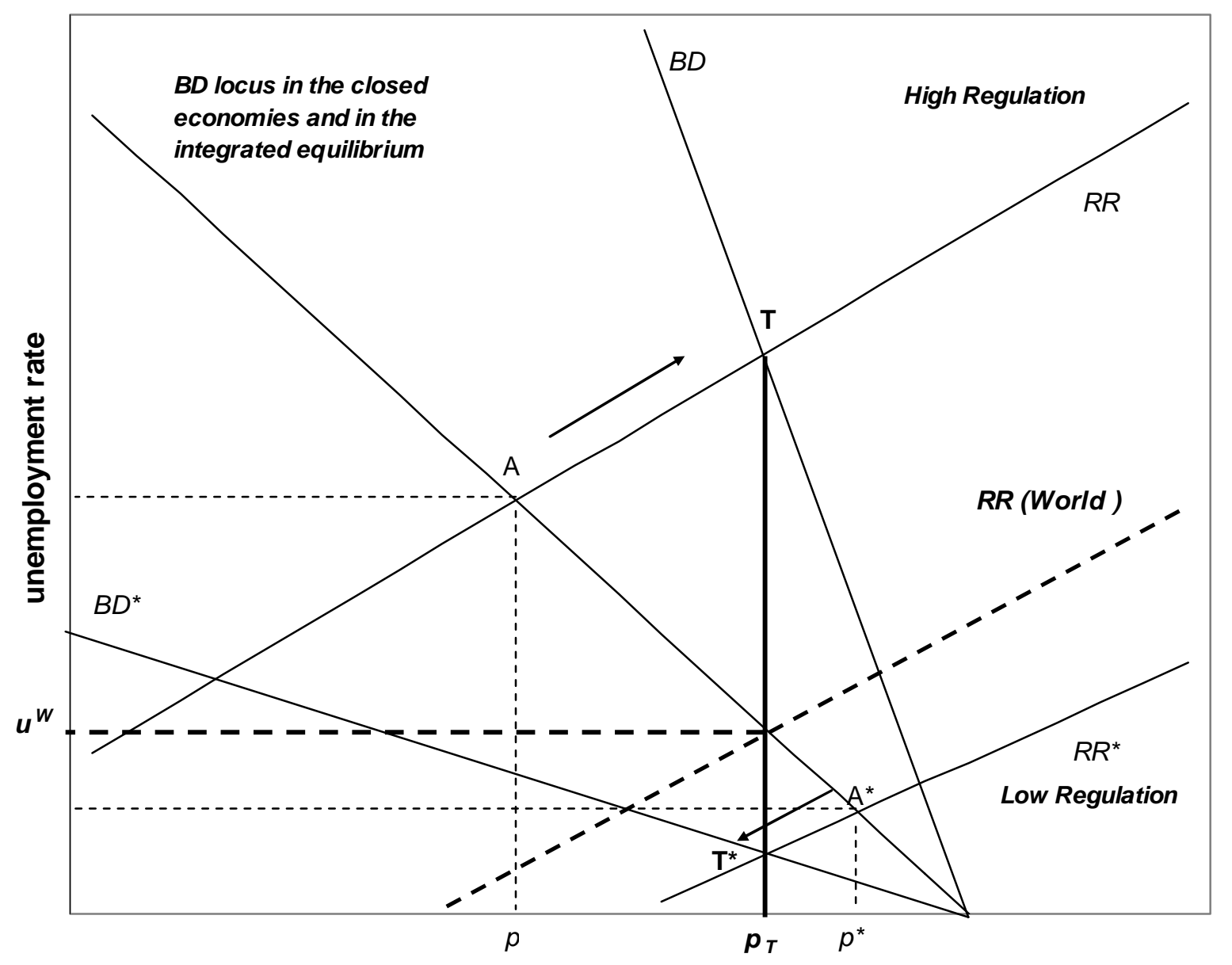

$p$, relative price of the capital intensive good (or user cost of capital) 
Figure 3B

Trade between two countries having identical relative factor endowment

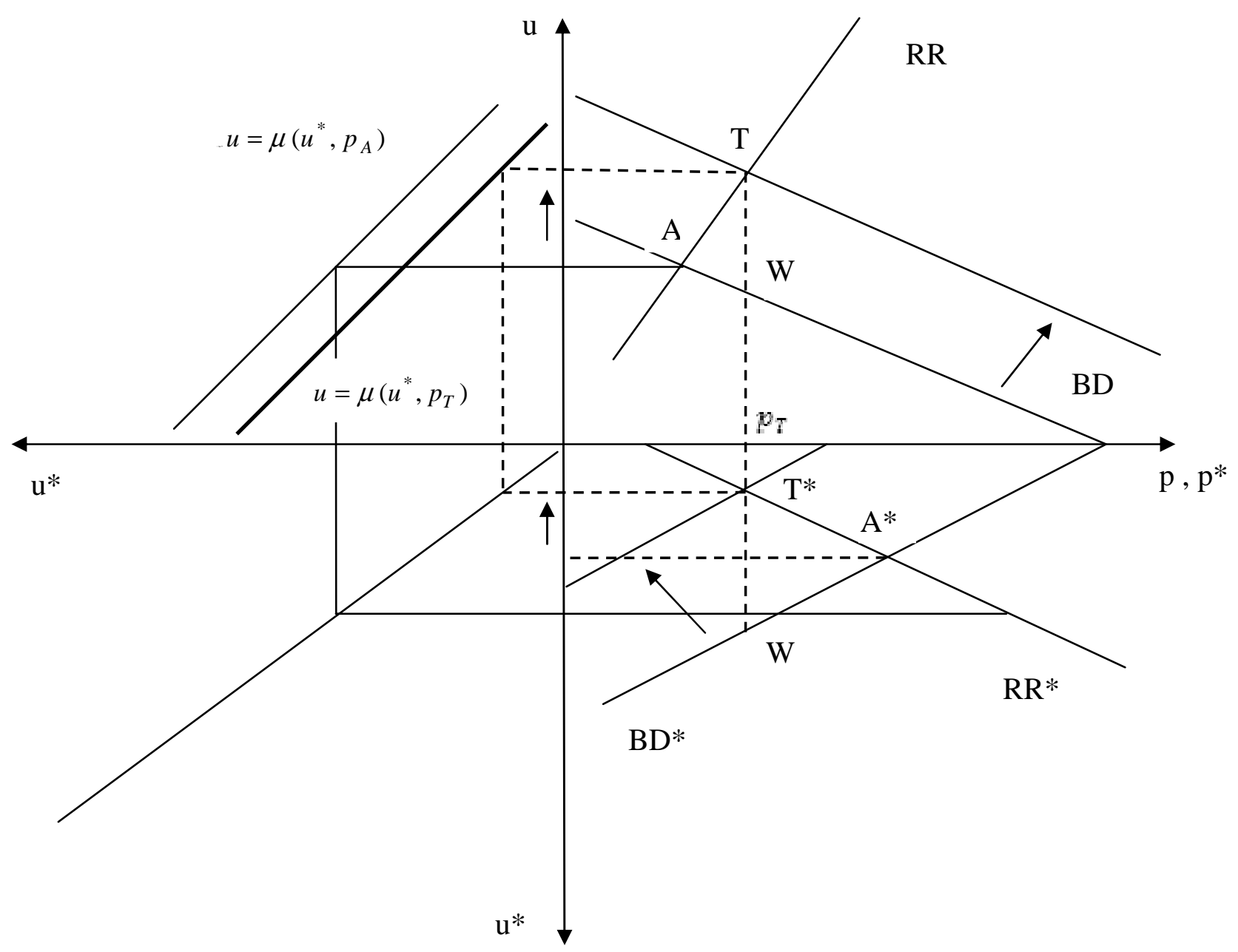


Figure 4

Trade between two countries having identical labor market regulation, but different relative factor endowments

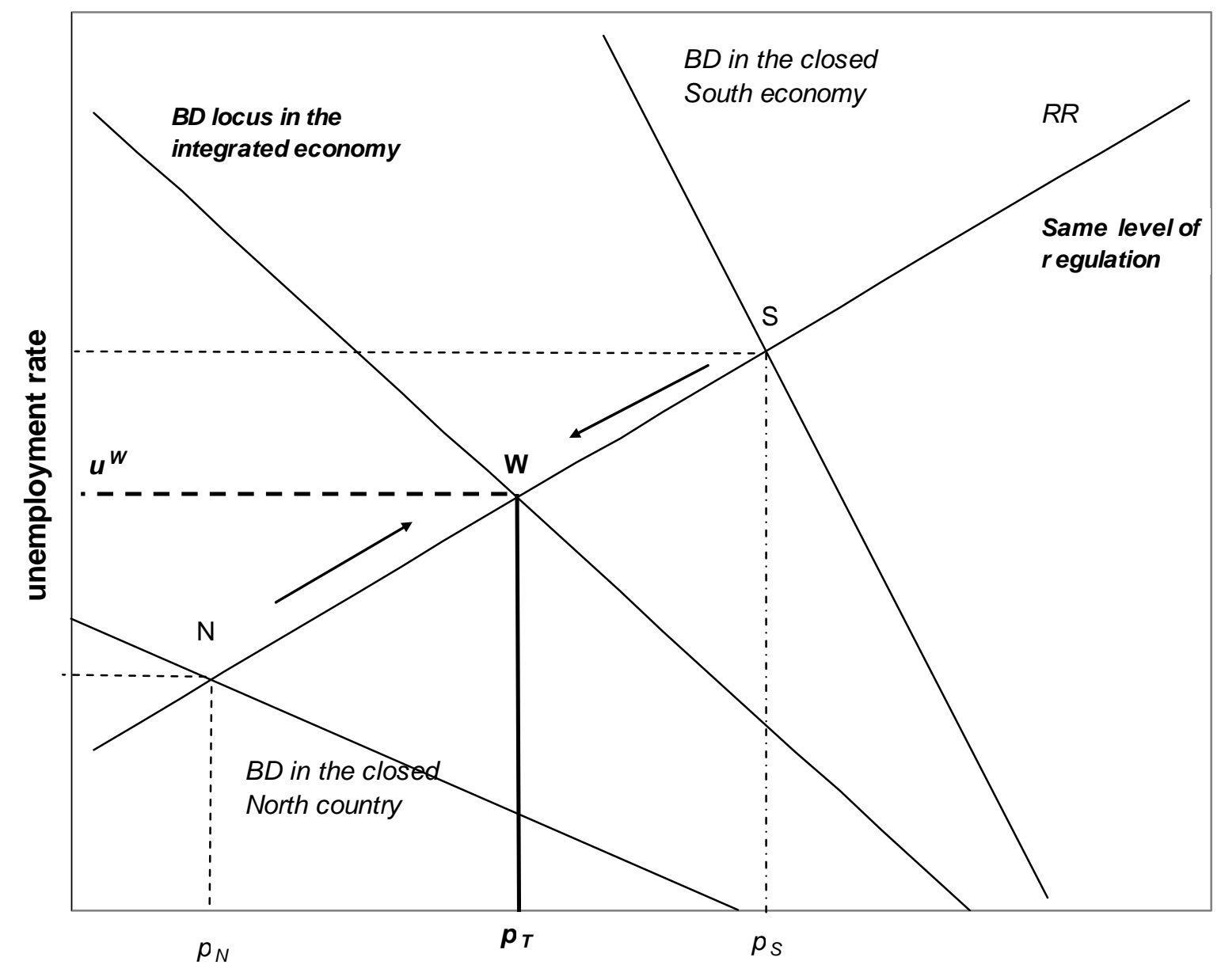

